\title{
A FRAMEWORK FOR STRUCTURAL MODELLING OF AN RFID-ENABLED INTELLIGENT DISTRIBUTED MANUFACTURING CONTROL SYSTEM
}

\author{
A.V. Barenj $\mathrm{i}^{1}$, R.V. Barenj $\mathrm{i}^{*}$ \& M. Hashemipour ${ }^{3}$ \\ ${ }^{1,3}$ Department of Mechanical Engineering \\ Eastern Mediterranean University, \\ Famagusta, North Cyprus, Turkey \\ ${ }^{2}$ Department of Industrial Engineering \\ Hacettepe University, Beytepe Campus \\ Ankara, Turkey \\ Reza.vatankhah@cc.emu.edu.tr
}

\begin{abstract}
A modern manufacturing facility typically contains several distributed control systems, such as machining stations, assembly stations, and material handling and storage systems. Integrating Radio Frequency Identification (RFID) technology into these control systems provides a basis for monitoring and configuring their components in real-time. With the right structural modelling, it is then possible to evaluate designs and translate them into new operational applications almost immediately. This paper proposes an architecture for the structural modelling of an intelligent distributed control system for a manufacturing facility, by utilising RFID technology. Emphasis is placed on a requirements analysis of the manufacturing system, the design of RFID-enabled intelligent distributed control systems using Unified Modelling Language (UML) diagrams, and the use of efficient algorithms and tools for the implementation of these systems.
\end{abstract}

\section{OPSOMMING}

' $n$ Moderne vervaardigingsaanleg bestaan gewoonlik uit verskeie verspreide beheerstelsels soos masj ineringstasies, monteerstasies en materiaalhantering- en stoorstelsels. Deur Radio Frekwensie Identifikasie (RFID) tegnologie met hierdie beheerstelsels te integreer, verskaf ' $n$ basis vir intydse monitor en instel van die beheerstelsels se komponente. Met die regte strukturele modelleringbenadering is dit moontlik om ontwerpe byna onmiddellik te evalueer en verwerk tot nuwe operasionele toepassings. Hierdie navorsing stel ' $n$ argitektuur voor vir die strukturele modellering van ' $n$ intelligente verspreide beheerstelsel vir ' $n$ vervaardigingsaanleg deur middel van RFID tegnologie. Die klem word op ' $n$ behoefteanalise van die vervaardigingstelsel, die ontwerp van die RFID intelligente verspreide beheerstelsels deur UML diagramme en die gebruik van effektiewe algoritmes en gereedskap vir die implementering van die stelsels, geplaas.

\footnotetext{
* Corresponding author
} 


\section{INTRODUCTION}

A typical manufacturing facility has a centralised database containing the product data model (PDM), which holds information on the product [1], and the manufacturing data model (MDM), which holds information on the systems needed to manufacture the product [2]. Together, the PDM and MDM provide an optimal scheduling plan for all control subsystems [3], organised hierarchically (e.g., as factories, cells, and stations) through a central host computer. This centralised control is quite effective when the product variety is low and the output volume is relatively stable [4], but does not adapt well to highvariety, low-volume production, or to ad hoc situations requiring dynamic re-configuration of subsystems.

Radio Frequency Identification (RFID) is an emerging technology appropriate to a wide range of applications. RFID tags offer several broad advantages, including long-distance contact, programmability, generous local storage, and non-line-of-sight scan-ability [5]. In addition, RFID tags' resistance to magnetic interference, water damage, and high temperature make them very suitable for industrial applications [4, 6]. In particular, the use of RFID tags in manufacturing systems enables the collection and processing of realtime manufacturing and product information at all points of the value chain [7]. Replacing dedicated barcode on a centralised manufacturing control system with RFID tags may be considered an alternative for handling product complexity and process flexibility in a decentralised way.

The aim of this research is to explore and investigate the idea of using an RFID-enabled Intelligent Distributed Control System (IDCS) at a manufacturing facility. To this end, we propose a new RFID-enabled integrated architecture for structural modelling of a manufacturing facility, to serve as a roadmap for re-designing an existing system to achieve higher performance, productivity, and flexibility, as well as lower costs. We will also describe our agent-based framework for implementing a re-designed IDCS at a given facility, based on smart processing of information carried by RFID tags.

The maj or objectives of our research will be to:

- Investigate the shortcomings of current control architectures with an eye toward potential improvements based on RFID-enabled IDCSs;

- Design a new architecture for structural modelling of RFID-enabled IDCSs;

- Verify design instances with respect to existing systems; and

- Implement the proposed RFID-enabled IDCS at a manufacturing facility and evaluate its performance.

\section{FLEXIBLE MANUFACTURING SYSTEMS AND RFID TECHNOLOGY}

RFID is a recent technology that uses radio waves to transfer data from a tag (typically attached to some object) to an antenna or reader [8]. Tags can be classified as active, passive, and semi-passive. Radio frequency standard technology is similar to RFID readers in terms of its functionality and its ability to read data stored in the tag using antenna. The data stored in the tag can then be transferred to the computer and stored in a database. An RFID reader can also write real time state data from the RFID tag.

A Flexible Manufacturing System (FMS) is a manufacturing system capable of adapting, more or less promptly, to both predictable and unpredictable changes. The nature of this flexibility generally takes one of two forms: machine flexibility or routing flexibility [9]. Machine flexibility comprises a system's ability to produce new and different product types and to change the order of operations executed at a control node. Routing flexibility comprises a system's ability to use multiple machines to perform the same operation and to absorb large-scale changes in volume, capacity, capability, etc. 
Although RFID technology has been extensively applied in the fields of logistics, supply chain optimisation, warehousing, retailing, and transportation [10, 11], it has only recently been introduced to the field of manufacturing systems. Nevertheless, this emerging field has already received considerable attention from researchers who have recognised the great potential of RFID in providing component-specific data on operational status, and thereby making the production process less centralised and more flexible [12]. Wang et al. [13] employed RFID technology to track object movement through a flexible manufacturing assembly line. McFarlane et al. [14] developed an RFID-assisted technology for automated identification, manipulation, and assembly of customised products in an experimental assembly line. Huang et al. [15] built an RFID-based real-time manufacturing information system to control the flow of information and materials across an entire manufacturing floor. Zhang et al. [16] developed an RFID-based smart Kanban system for work-in-progress (WIP) management.

RFID technology has also been used to enhance the intelligence of control systems. Satoh [17] combined mobile agents with RFID-based location sensing systems. Bellifemine et al. [18] proposed the JADE (J ava Agent Development) framework for developing agent-based applications in compliance with FIPA (Foundation for Intelligent Physical Agents) specifications for interoperable intelligent multi-agent systems (MAS). Shafiq et al. [19] proposed a method for making MAS compatible with existing web service standards. Tapia et al. [20] described a flexible user- and service-oriented multi-agent architecture called FUSION.

The literature reviewed by the authors indicates that existing working attempts are valuable for informing the application of RFID technology in a manufacturing system. There is, however, no standard, empirical methodology for how a company should apply RFID technology to IDCS, given the unique complexities of most manufacturing systems. It has been suggested that unwieldy documentation, and a lack of a communication between the user, the system designer, and the implementer, have been the major barriers to adopting new technology into existing systems [21]. Recognising that structural and behavioural modelling have been the primary means for requirement analysis and re-design of manufacturing systems, the authors believe that this is a good starting point for developing an RFID-enabled IDCS. It creates a robust communication link between manufacturing system designers, users, and implementers, and provides a useful basis for evaluating designs and translating them into operational applications.

\section{STRUCTURAL MODELLING, APPROACHES AND TOOLS}

An important step in the design or re-design of a system is to provide an abstract representation of the system's resources and activities for the design team [22]. A so-called structural model provides this representation. In the case of retrofitting, this structural model is used to capture the functionality of the existing system for the purpose of improving its performance, productivity, and/ or cost-effectiveness [23].

The purpose of structural modelling is to produce a conceptual schema of entities and their relationships in order to (1) facilitate the process of communication among the system stockholders, (2) establish a common model that can accommodate the different needs of individuals and organisations within the enterprise, and (3) produce a logical model that can be implemented. In practice, two approaches to structural modelling have dominated: the procedural approach and the object-oriented approach. Both approaches cover the same aspects of a system (e.g., processes, activities, and objects), and may employ a variety of existing tools such as IDEF0, Data-flow diagrams (DFD), and Unified Modelling Language (UML).

We have chosen to use an object-oriented structural modelling approach based on UML. Under this approach, the modelled world is composed of basic elements or objects (e.g., the machines on a manufacturing floor) that tightly bind both data (attributes) and operations (methods) while hiding implementation details. The abstraction of objects with 
common characteristics forms a class, and an object is said to be an instance of this class. Systems are built via construction of objects and their relationships, revealing the inheritance, composition, and associations between classes [24, 25].

UML is a graphical modelling tool that enables system stockholders to design and reference object-oriented systems [25]. UML offers a way to visualise a system's architecture using different diagrams, including use case diagrams, class diagrams, activity diagrams, and sequence diagrams. For the authors' purposes, UML holds several advantages over other paradigms and modelling languages: (1) UML has been successfully applied to a wide range of industrial applications [26]; (2) the software of most modern machines can be modelled with UML; (3) UML allows the integration of techniques such as business modelling, object modelling, and component modelling; and (4) UML provides an information-rich representation that can be tested for consistency, analysed, and translated into other representations.

\section{PROPOSED ARCHITECTURE FOR RFID-ENABLED IDCSS}

The proposed architecture is composed of a system requirements phase, a design and development phase, and an implementation phase. Each of these phases comprises a system level, a data level, and a sensor level. In the system requirement phase, the current system specification is captured holistically, and problems that might be improved by RFID technology are identified. In the design and development phase, the manufacturing system is re-designed to address the problems identified in the system requirements phase. This phase produces, at the system level, a number of use case diagrams, class diagrams, object diagrams, and sequence diagrams. At the data level, structural points are represented using cell activity and development diagrams. At the sensor level, the details of integrating RFID technology are captured through sequence, component, and class diagrams. A verification process ensures that the newly-designed structure fulfils the requirements of the existing system. Ultimately, in the implementation phase, a hardware configuration and multi-agent framework are expressed at the system level, and interaction details are provided at the data and sensor levels.

This proposed architecture will be illustrated by a case study of a manufacturing facility composed of a single cell with three stations. This facility is physically located in the FMS laboratory at the Eastern Mediterranean University in Cyprus (see Figure 2).

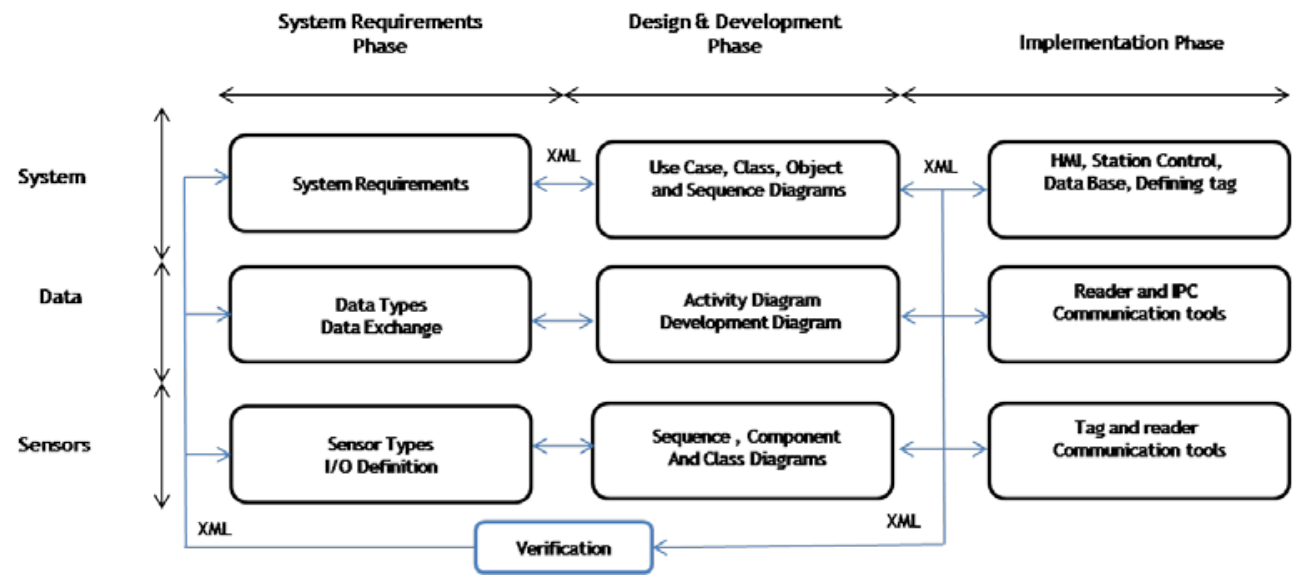

Figure 1: Proposed architecture for RFID-enabled FMS 


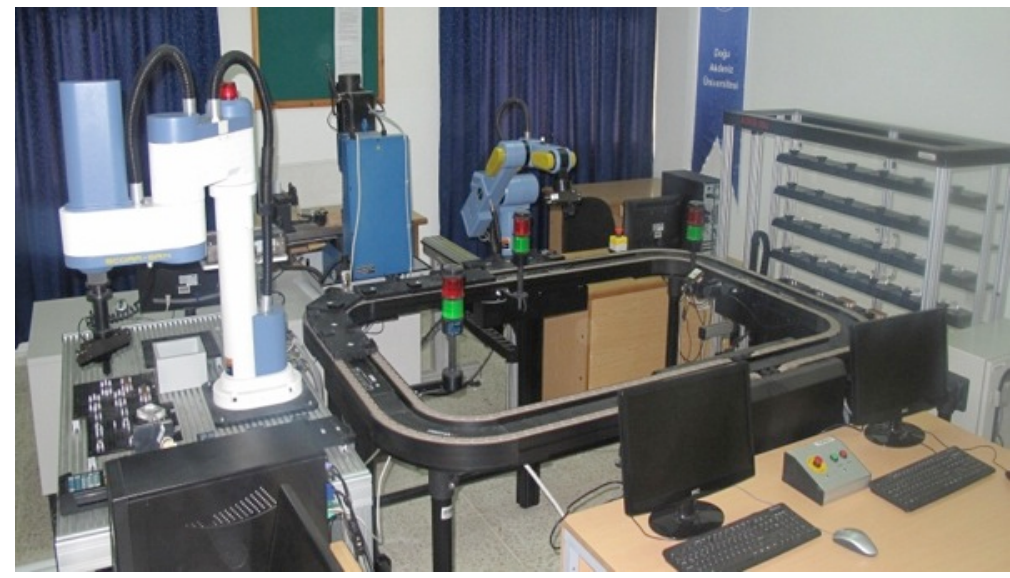

Figure 2: FMS laboratory at the Eastern Mediterranean University

\section{SYSTEM REQUIREMENT PHASE}

The FMS laboratory at EMU was designed for education and research purposes. The laboratory consists of three stations:

- $\quad$ Station 1 is a machine tending station consisting of a CNC milling machine and a fiveaxis vertically-articulated robot (SCORBOT - ER 9) designed for use in an industrial training facility;

- $\quad$ Station 2 is an assembly and quality control station containing one SCORA ER 14 robot (from Intelitek). This robot has a pneumatic gripper, and works in connection with peripheral station devices, including a ball feeder, gluing machine, and laser-scan micrometer device (from Mitutoyo); and

- Station 3 is an automatic storage and retrieval system (AS/RS) with 36 storage cells and a robot capable of articulating work pieces. A conveyer joins the three stations inside the cell.

The two robots are equipped with multi-tasking controllers that provide real-time control and synchronisation of up to 12 axes of motion, and 16 inputs and outputs. These two robots are able to support both stand-alone applications and sophisticated automated work cells. The overall system runs on a supervisory host control consisting of a set of Industrial Personal Computer (IPC) stations, a Programmable Logical Control (PLC) for controlling the conveyor, and a host computer that manages the cell orders using Open-CIM software.

Barcode technology is used within the cell to identify a part type with the appropriate machine (e.g. robot, CNC machine) and to trace batches of components (i.e., all components with the same product operation list).

The problems with the current control architecture that might be improved by RFID technology are as follows:

- The manufacturing system is controlled by a centralised architecture running on a single host computer, from which all control decisions are issued;

- The stations have no autonomous control unit for their operations;

- The barcode technology cannot provide real-time information on component presence/ position or on production progress,

- The barcode technology is not suited to tracking new products one-by-one; and

- The system cannot be re-configured in real time. 


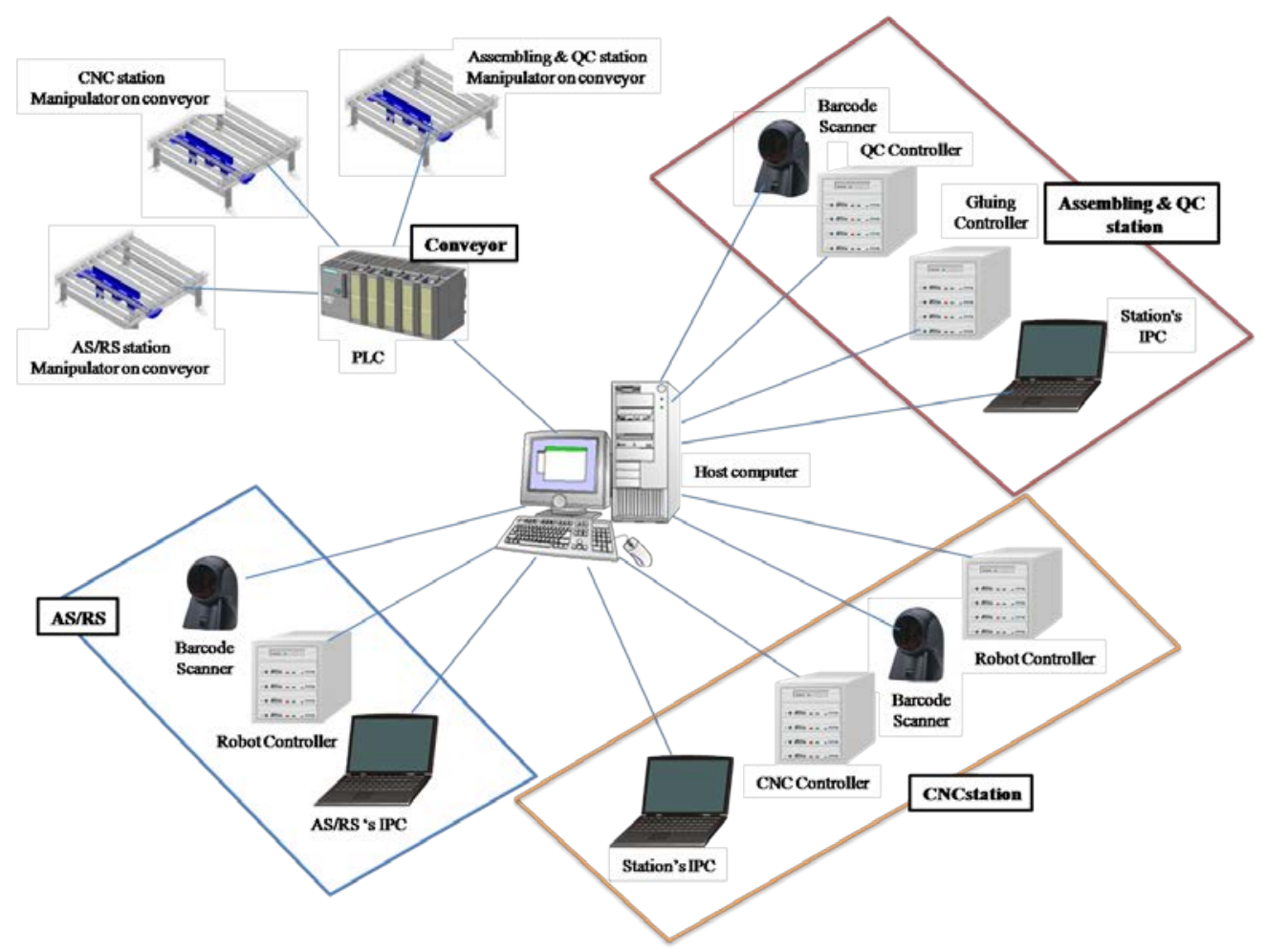

Figure 3: The connections and hierarchical relationships of the FMS

Development of an RFID-enabled IDCS to address these problems is justified as follows:

- When a part is complex, it may lack a convenient and scannable location for barcodes. RFID tags can be placed anywhere on the part, and scanned from any orientation;

- Unlike barcodes, RFID tags can store data for continuous production updates;

- Unlike barcodes, RFID tags are unaffected by the dust and grime commonly found in industrial environments; and

- $\quad$ RFID tags can provide monitoring of the arrival, continuous presence, and departure of specific parts to/from a cell, allowing for better management of routes and locations in the assembly environment.

\section{DESIGN AND DEVELOPMENT PHASE}

\subsection{System level}

A use case diagram is an appropriate tool for illustrating working connections among the users and stakeholders of a system, and for demonstrating the structure and behaviour of entities at the highest level of abstraction. Figure 4 shows schematically how the operator of the system can interact with the human/machine interface (HMI). The upper rectangle of Figure 3 contains the two use cases for HMl: monitoring and controlling. The link between this HMI rectangle and the operator indicates that the operator is charged with controlling and monitoring the system. Machining, assembling, and ASRS are the main use cases of the overall system, as represented by the lower rectangles, which are connected to the HMI rectangle by specialisation arrows. These rectangles contain further specialisations of their use cases. For instance, the ASRS use case contains actions for processing, storing, moving, and sensing. 


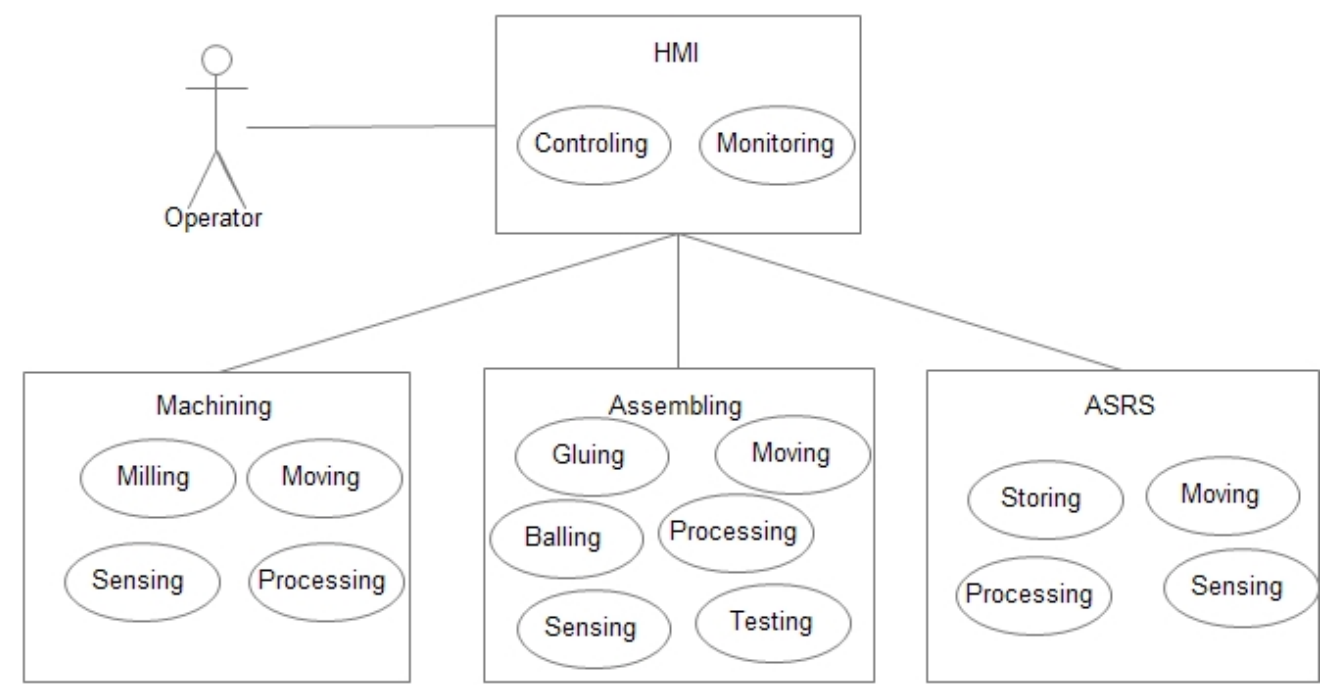

Figure 4: Shop human/machine interface

A class diagram is a static view of the system and its object orientation. Figure 5 depicts the main modules of the target system and their interconnections. The top part of this diagram shows the hierarchical model of a manufacturing facility, or 'shop'. A shop can encapsulate a number of cells, each of which may contain several stations.

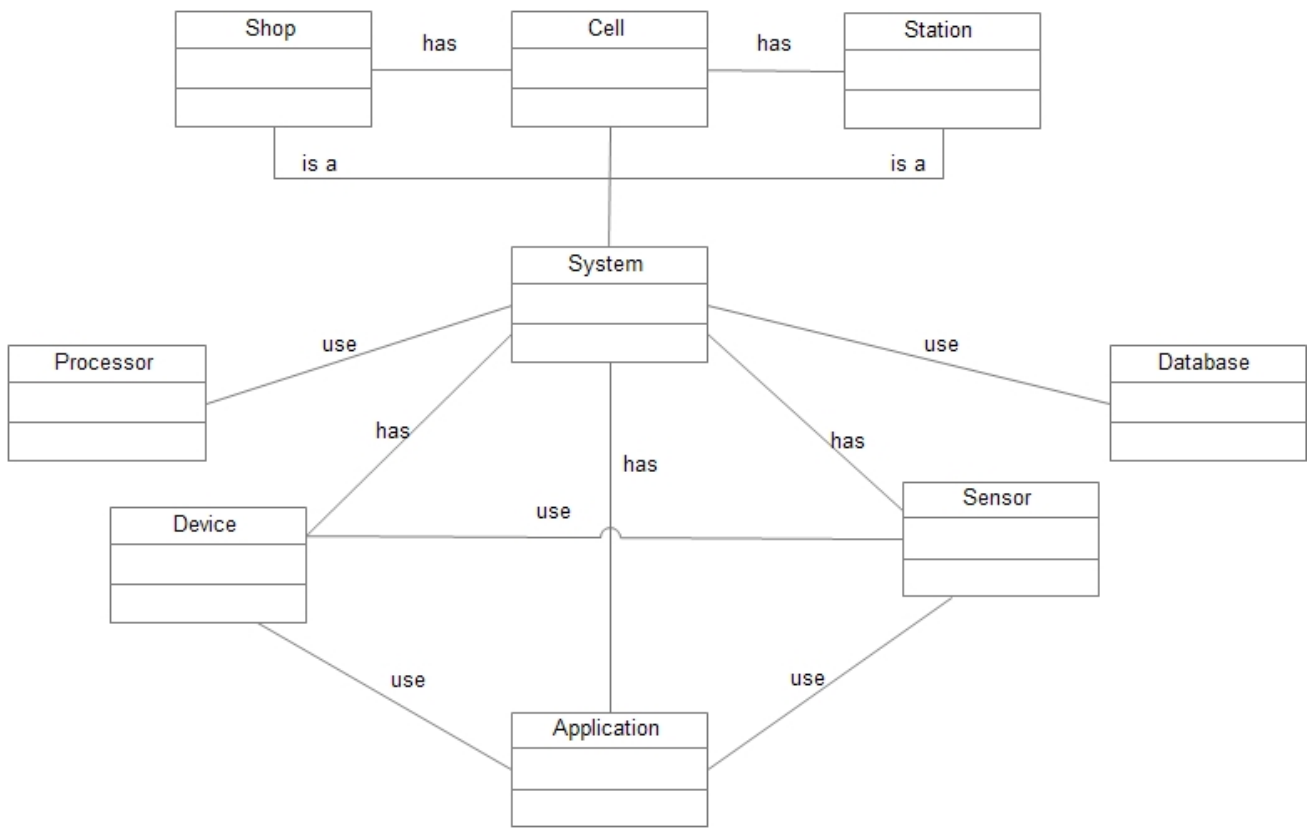

Figure 5: Generic class diagram of a target manufacturing system (MS)

A UML object diagram demonstrates static aspects of the system's building blocks. In the authors' target system, a station contains several resources representing mechanical and electrical components, connected by means of an IPC. All the stations in the shop form a network, which is then connected to the HMI. Figure 6 shows an object diagram for machining stations.

A station contains several devices, applications, and an RFID-gate that integrates with an IPC and connects to a data bus. The station's UML sequence diagram will help system 


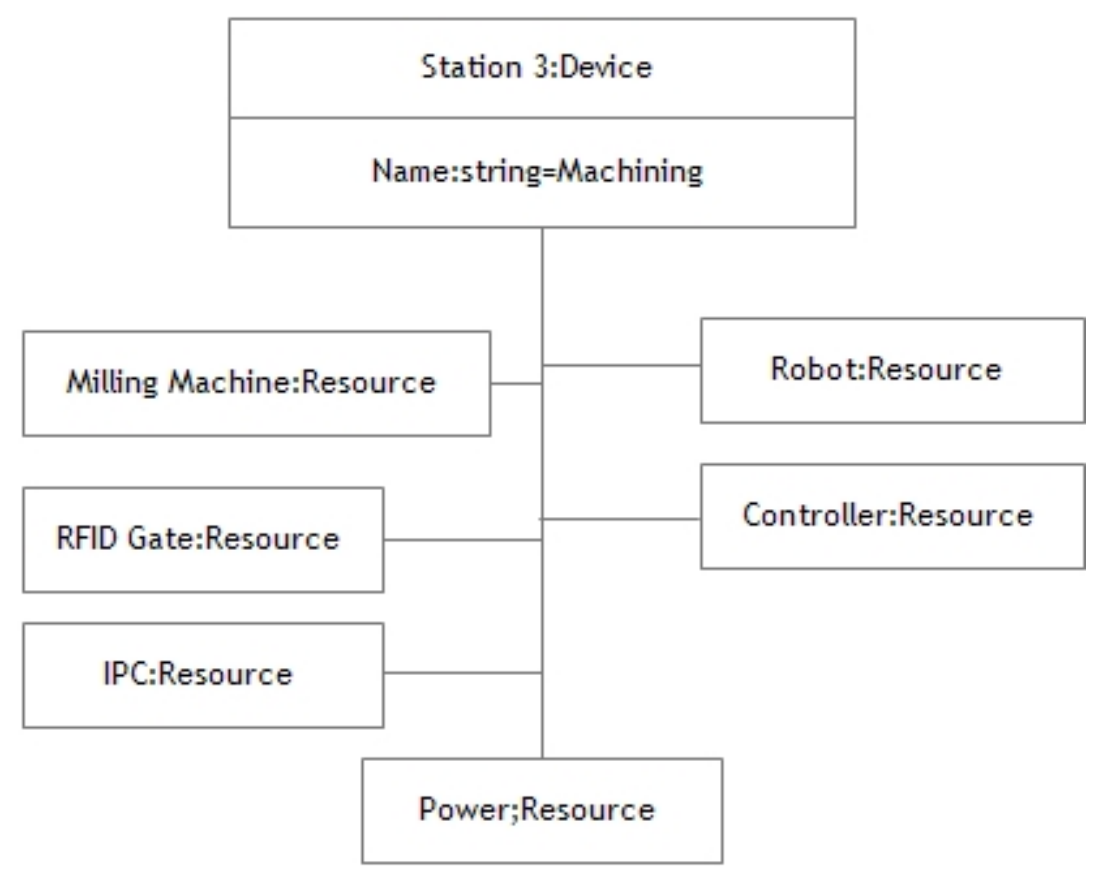

Figure 6: An object diagram for machining station's UML

analysers and developers understand the dynamic behaviours of stations. A station receives messages from a part's tag and performs services accordingly. The station's RFID-gate then reads the same message and, based on its content, permits subsequent operations. Several operations based on the scenario can be executed in the machining, assembling, and AS/ RS stations. A sample operation for the assembling station is illustrated in Figure 7.

\subsection{Data level}

The data level presents the data flow and data connections among cell components. These may be expressed through structural and/ or behavioural diagrams. Specifically, structural modelling is depicted through activity diagrams of the cells, while behavioural modelling is represented through development diagrams of the cells.

The UML activity diagram of the cell (see Figure 8) provides a clear graphical schematic for implementation, as well as verification parameters.

This diagram is divided into three layers: machining, assembly, and AS/ RS. In each of these layers, an RFID-gate containing two antennas is integrated with a reader. The product development chain starts with a request from HMI to AS/ RS. In response, AS/RS provides a part (in this case, raw material) to the conveyer. The RFID tag attached to this part stores lifecycle information for the production system and is updated by the RFID-gates. This information includes, but is not limited to, the universal identification number, parts number, station identification, processed status for a station, delivery deadline, and order number. The RFID-gate of the machining station reads the part information and instructs the station's robot to pick the part up and place it in the appropriate position. The RFIDgate also sends process-related information to the station IPC to request a machine controller for the machining process. When this process is finished, the robot takes the part from the machine and puts it on the conveyor. As the part passes through the station RFIDgate, its information (i.e., processed status) is updated. This cycle is repeated at subsequent stations until the product is finished and placed at a suitable position in the AS/ RS. 


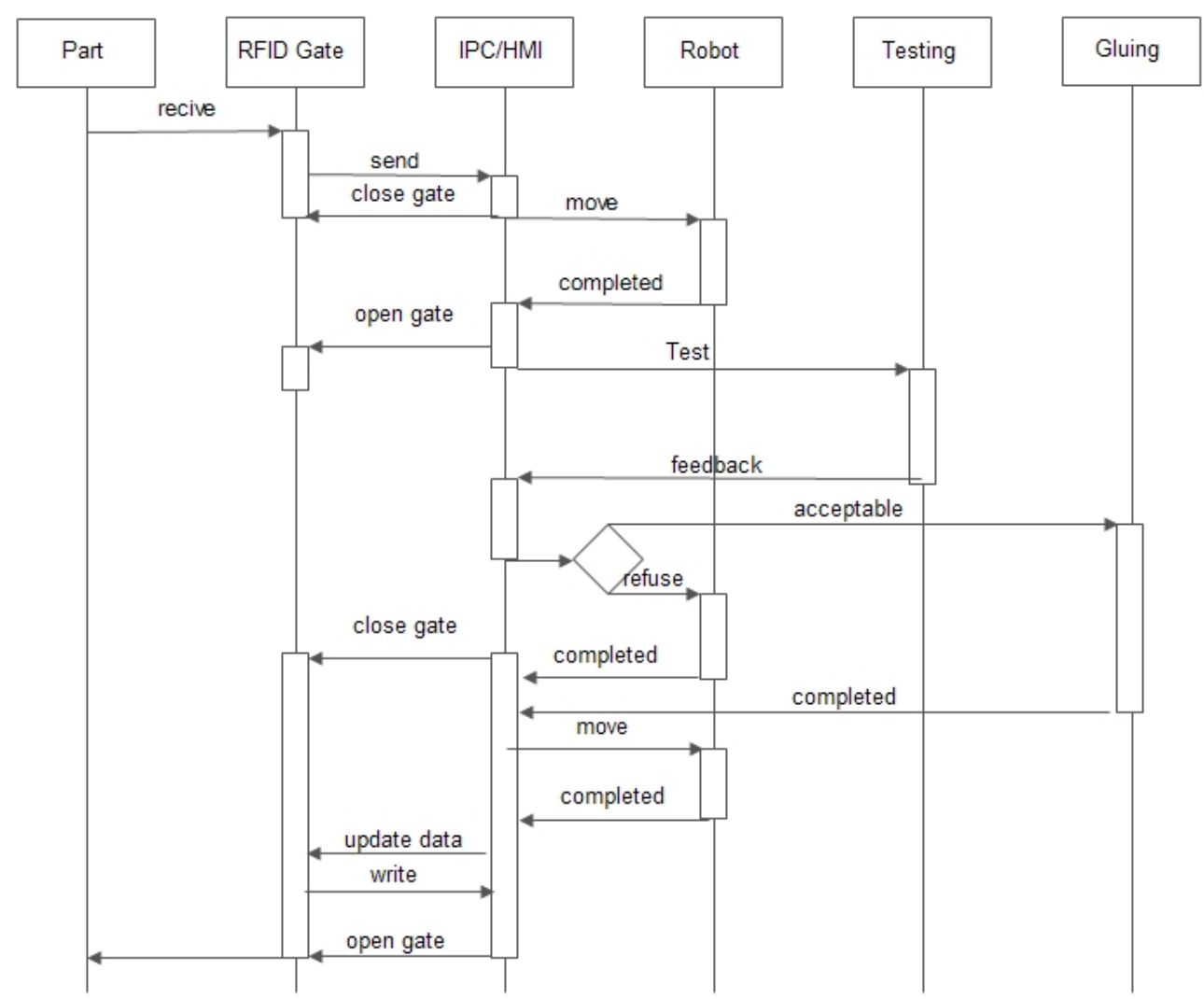

Figure 7: A sequence diagram for an assembling station's UML

A UML deployment diagram provides an implementation view of the stations. A deployment diagram for a cell is shown in Figure 9. Note that each station consists of several components, connected via a wireless communication link. Information on a given part is shared among the stations of the cell before it is forwarded to the HMI.

The HMI can process as well as transmit/receive, and can therefore be connected directly to the Internet for remote control via TCP/IP.

\subsection{Sensor level}

Integrating RFID technology in a manufacturing system enables real-time information about products in the value chain. This information can be used to improve system productivity, agility, and flexibility. It is also vital for real-time re-configuration, since local information storage allows for a more decentralised production system.

Schematically, an RFID system is composed of a tag, an antenna, and a reader. Data is stored on the tag, read or written by the antenna, and sent to the reader, which decodes and forwards it elsewhere in the system (see Figure 10).

In the proposed manufacturing cell, the station's RFID-gate is used not only for scanning parts but also for updating tag information and loading/ unloading stations. Parts are delivered to stations according to their next station's ID. Each station receives parts from its RFID-gate. The station IPC then performs some operations on the part before placing it back on the conveyor. The component diagram for an RFID-gate is illustrated in Figure 11.

The part tag allows the RFID-gate to switch and route mutually-connected conveyors automatically, so that the part is transported to the desired station. 


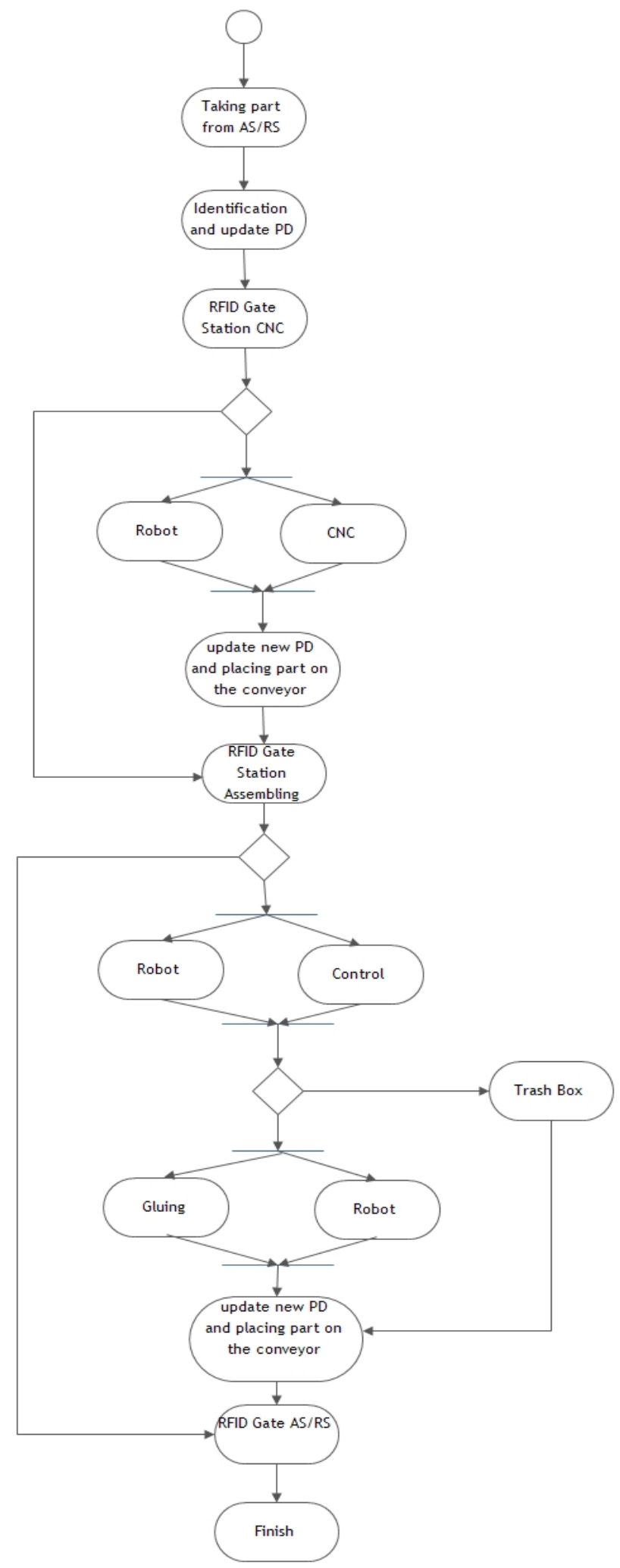

Figure 8: UML activity diagram of a cell 


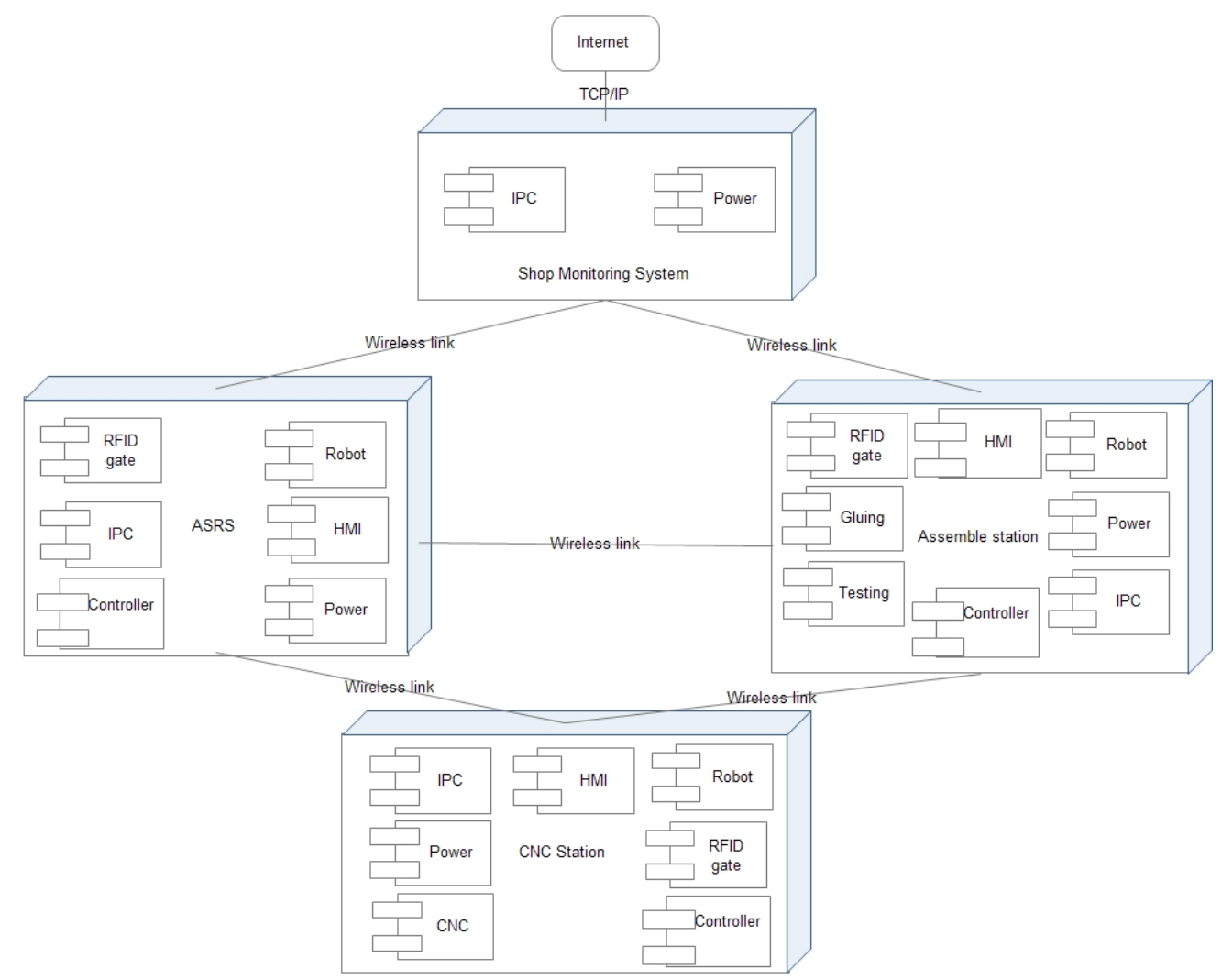

Figure 9: UML deployment diagram of the cell

\section{VERIFICATION PROCESS}

The verification block compares data generated during the system requirement phase with data generated during the design and development phase. This process helps to determine whether the designed model meets the problem definition. Extensible Mark-up Language (XML) is used to encode exchanged information (see Figure 12). The data file generated at the system requirement phase consists of three groups of information $[27,28]$ :

1. Supporting data structures: (a) measurement units (time units); (b) statistics (standard deviations, average, state time, and running time); (c) model references (model name, user, date, and time).

2. Objects negotiation data structures: (a) message name; (b) start message element; (c) end message element; (d) start messaging time; (e) end messaging time. As models are processed during the design and development phase, their UML diagrams are transformed into new data files. After the consistency rules have been applied to these files, a matching environment that captures differences between two data files is ready to perform the verification.

3. Manufacturing data structures: (a) element name; (b) element class; (c) resources (machines, labourers, etc.); (d) operations lists; (e) events lists; (f) element failures; (g) daily schedules; (h) element busy time; (i) element idle time. 


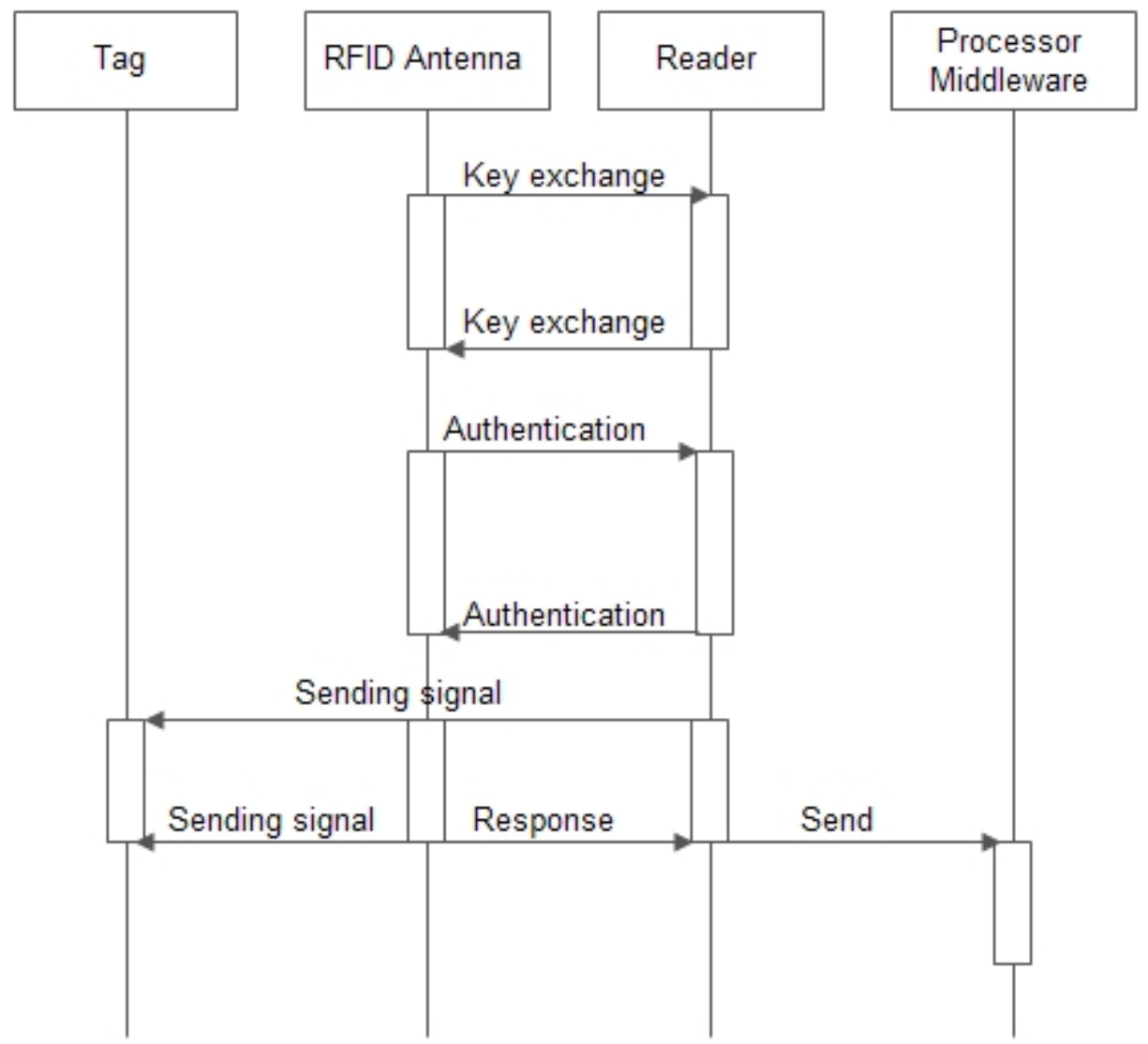

Figure 10: Relationship between RFID antenna and the reader

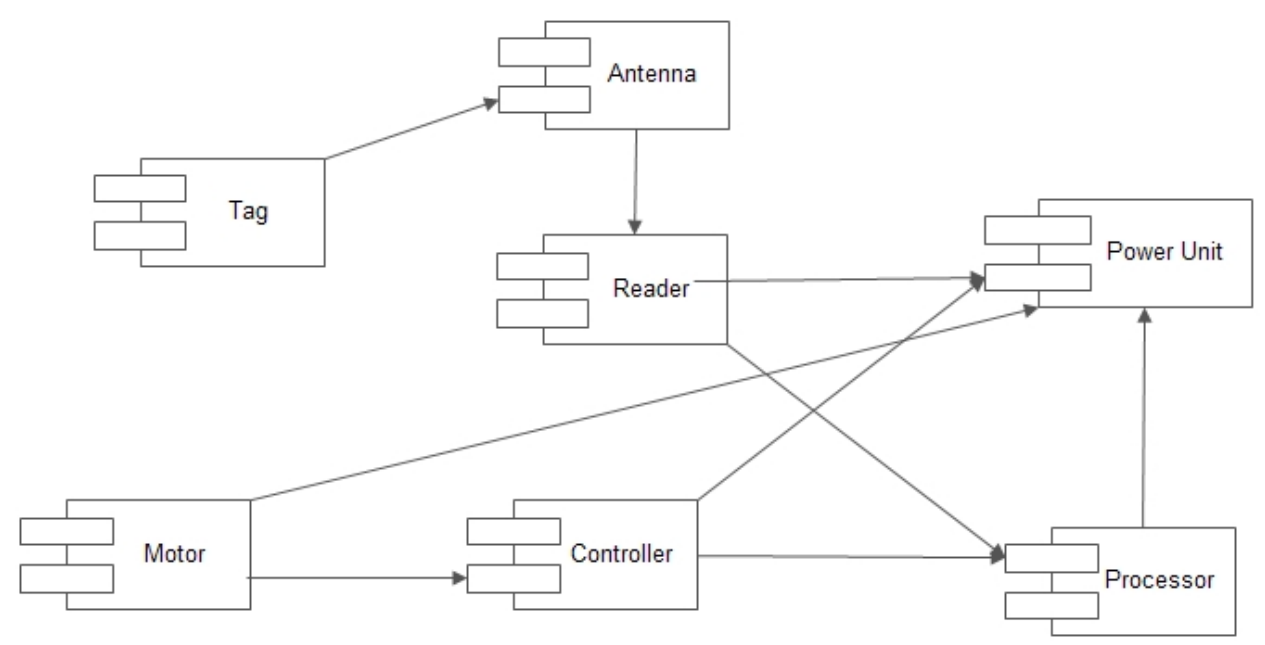

Figure 11: Component diagram of an RFID-gate

\section{IMPLEMENTATION PHASE}

The proof of correctness and validation of the developed architecture was performed through the implementation phase. The application was completed as a part of the doctoral 


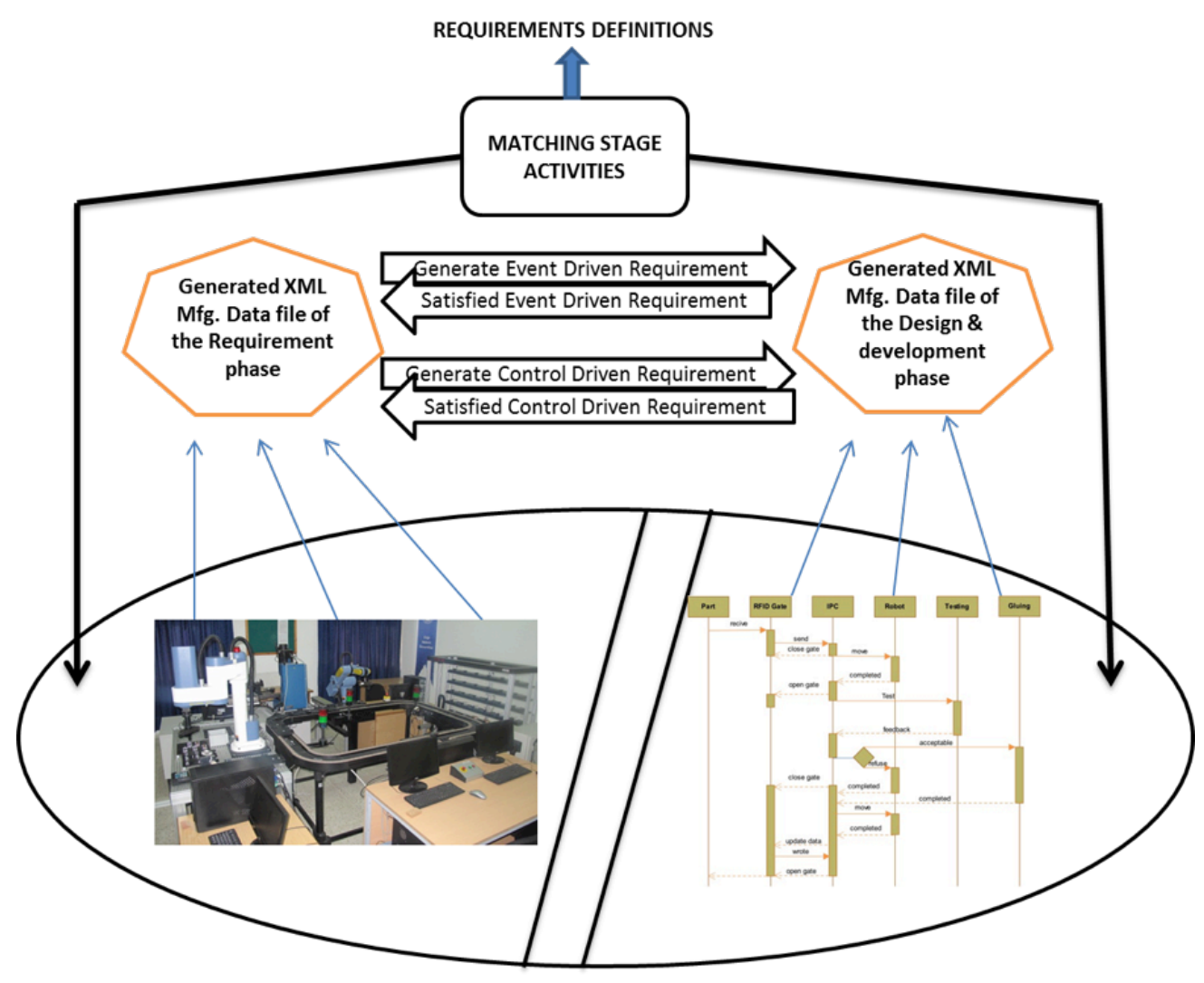

Figure 12: Verification environment

thesis of one of the authors and is described in [32]. The major concerns during the implementation phase are software and ICT development for the purposes of (a) controlling stations, (b) monitoring the real-time state of products at stations and cells, (c) storing data, (d) communicating and transforming data from readers to station IPCs, and (e) defining a new part operation list.

The agent concepts offer a new approach for implementing diverse autonomous applications. A multi-agent system consists of a number of agents that work together to find answers to problems that are beyond the individual capabilities or knowledge of each entity. These agents interact with one another, typically by exchanging messages through the computer network framework [29, 30,31].

\subsection{Multi-agent system framework}

Our RFID-enabled IDCS is designed as a network of software agents that interact with each other and with system actors. These agents include the Shop Management Agent, Agent Manager, Shop Monitoring and Command Agent, Station Control Agents, Station Monitoring Agents, Agent Machine Interface, and Manufacturing Resource Agent [32]. The framework also includes a shop database and station database, and a knowledge model [33] for interagent communication.

The functionality of the main software agents in the proposed multi-agent system is as follows:

- $\quad$ The Shop Management Agent (SMA) is responsible for helping a shop manager define a new product for the system, specify initial manufacturing parameters, and decompose 
product operation for the system. It has a user interface for assisting the shop manager in making necessary changes as the plan gets more detailed.

- The Agent Manager (AM) is responsible for controlling the availability and use of all agents by maintaining an accurate re-presentation of their activities and a means of inter-agent communication.

- The Shop Monitoring and Command Agent (SMCA) is responsible for obtaining and displaying the real-time state of raw materials, in-process products, and finished products, as well as the status of stations. The SMCA also serves as a port for incoming manual commands from the shop supervisor.

- The Station Control Agent (SCA) selects suitable capabilities from the product operation list for a station, and requests capabilities from basic agents to perform a job. The SCA may update state data at the station's database, and send control instructions to the shop database.

- $\quad$ The Station Monitoring Agent (SMoA) tracks the manufacturing state of a station and stores state history in the station database.

- The Manufacturing Resource Agent (MRA) represents specific manufacturing components (e.g., robots, conveyors, machinery) as encapsulations of the capabilities, interaction behaviours (e.g., collective capabilities), and internal status that characterise those components.

- $\quad$ The Agent-Machine Interface (AMI) acts as a kind of device driver to the MRA. For each different controller there should be one agent machine interface.

All agents are connected by a local area network (LAN) through which they communicate with one another via asynchronous message passing. To keep SMCA performance high, the SMA and AM run on an application server, the knowledge model operates on the data server responsible for maintaining the shop database, and the SCA, SMOA, MRA, and AMI, along with the station's database, operate on the station's IPC.

\subsection{Hardware configuration}

Based on the multi-agent framework for RFID-enabled IDCS proposed in Section 8.1, we propose the hardware architecture depicted in Figure 13. This includes all station resources (e.g. CNC milling machine, robot), station controllers, and station IPCs. The new components to be added to the EMU-FMS lab are as follows:

- 20 RFID active tags (FS1001T active RFID tags). Each tag is attached to a part.

- An RFID-gate (see Figure 14) for each station, including:

a) Motorola's AN480 antenna, installed on the front of each station;

b) Motorola's FX7400 RFID reader, installed near the station's IPC; and

c) A manipulator for loading/ unloading parts at the stations.

- 3 IPCs*.

- A PC for the Shop Monitoring and Command Agent*.

- An application server*.

- A data server*.

- 3 Panel Master PL035 7.2" displays, used for monitoring the real-time state of production at the stations.

* single PC running Microsoft Windows XP

\subsection{Agents and engineering tools}

The MAS for our RFID-enabled IDCS was implemented using C\# and the . Net Framework. The .NET Framework, a runtime execution environment . NET application, consists of the common language runtime, which provides memory management and other system services, and an extensive class library offering robust, reliable functionality for all major areas of application development.

The Microsoft SQL Server database management system is used for development of the shop and stations databases. The C\# source code for the reader was acquired from the manufacturer's website (www. motorolasolutions.com). All code for 'Shop Management 


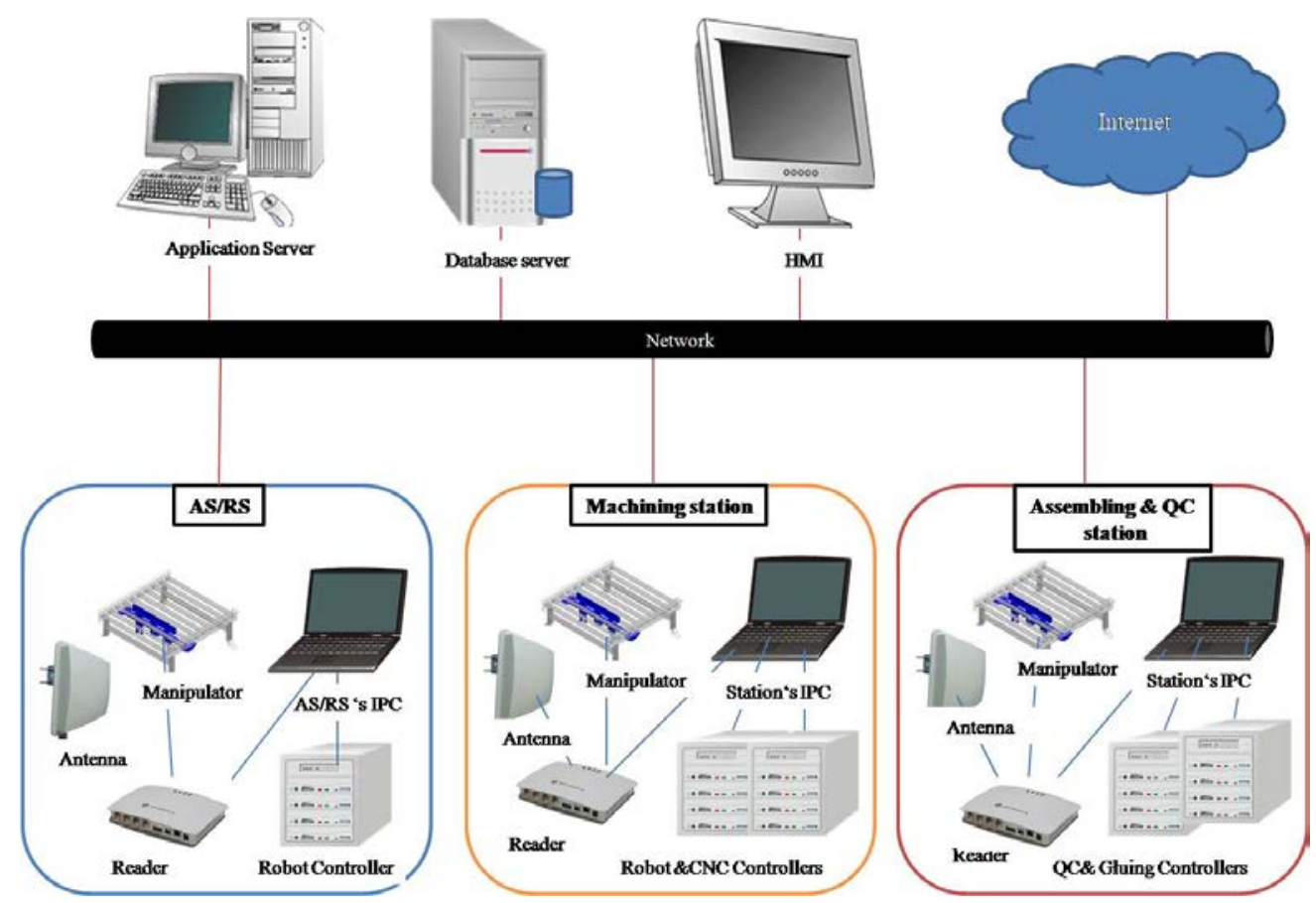

Figure 13: Hardware configuration

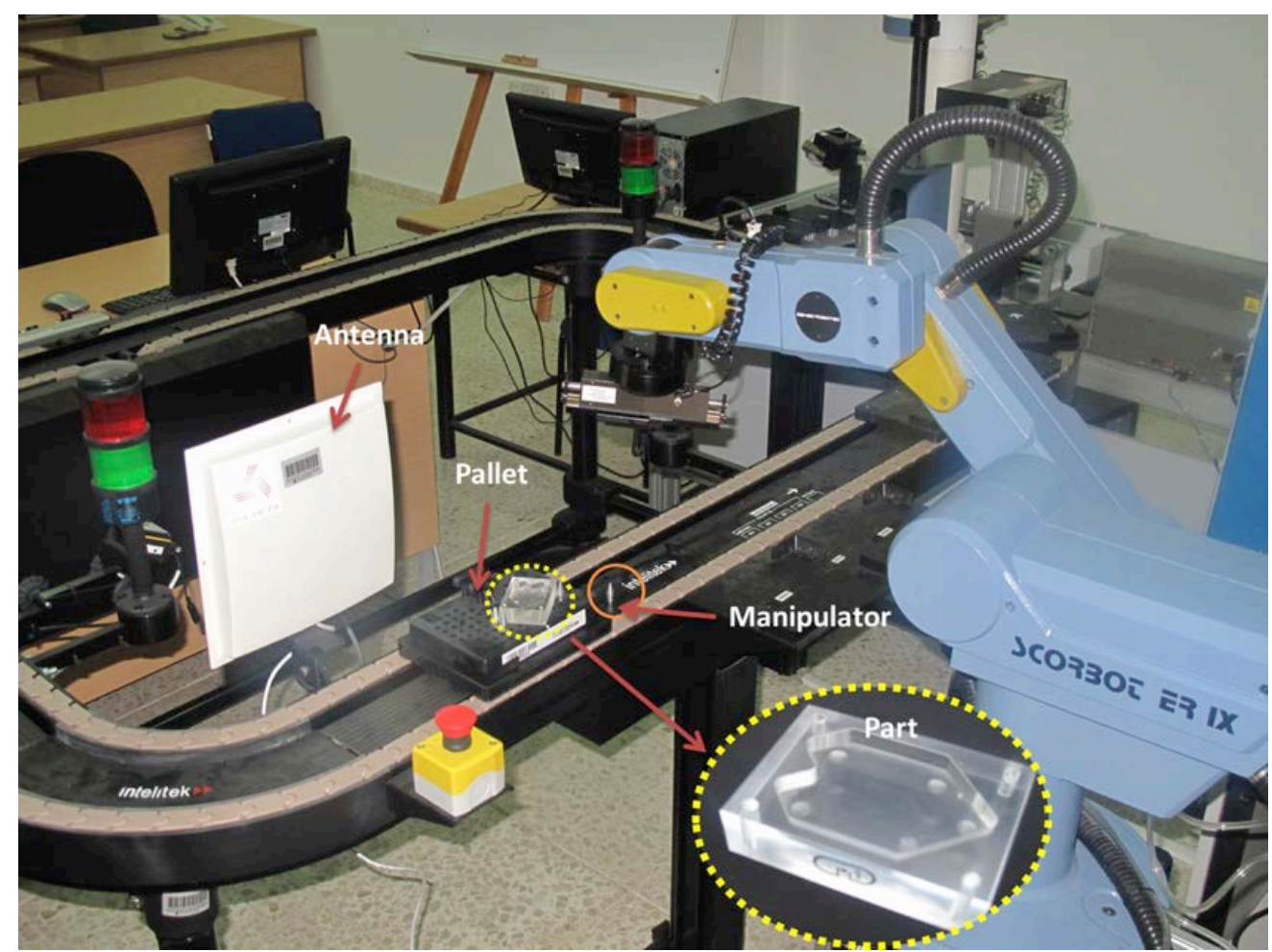

Figure 14: Machining station RFID-gate

Agent', 'Agent Manager', 'Station Control Agent', and 'Manufacturing Resource Agent' applications was written in C\#, while that of the 'Shop Monitoring and Command Agent' was developed in SWISH Max 4 software using the C programming language. The 'Station 
Monitoring Agent' and 'Agent Machine Interface' were developed in PM Designer 2.0 and PM Designer V1.2 respectively, using the built-in Macro Language.

\subsection{Interaction}

Cooperation between all agents requires a robust interaction schema that supports information exchange, handles errors, and avoids deadlocks and other abnormal stoppage conditions. All agents developed in C\# interact with the Microsoft SQL Server (e.g., station database, ontology) via the SQL DB Provider component, and with the 'Shop Monitoring and Command Agent' via the Shell Shockwave ActiveX component. For the connection between the 'Station Control Agent' and HMI using the RS232 port, the System IO Ports component was used. Figure 15 illustrates the shop monitoring system.

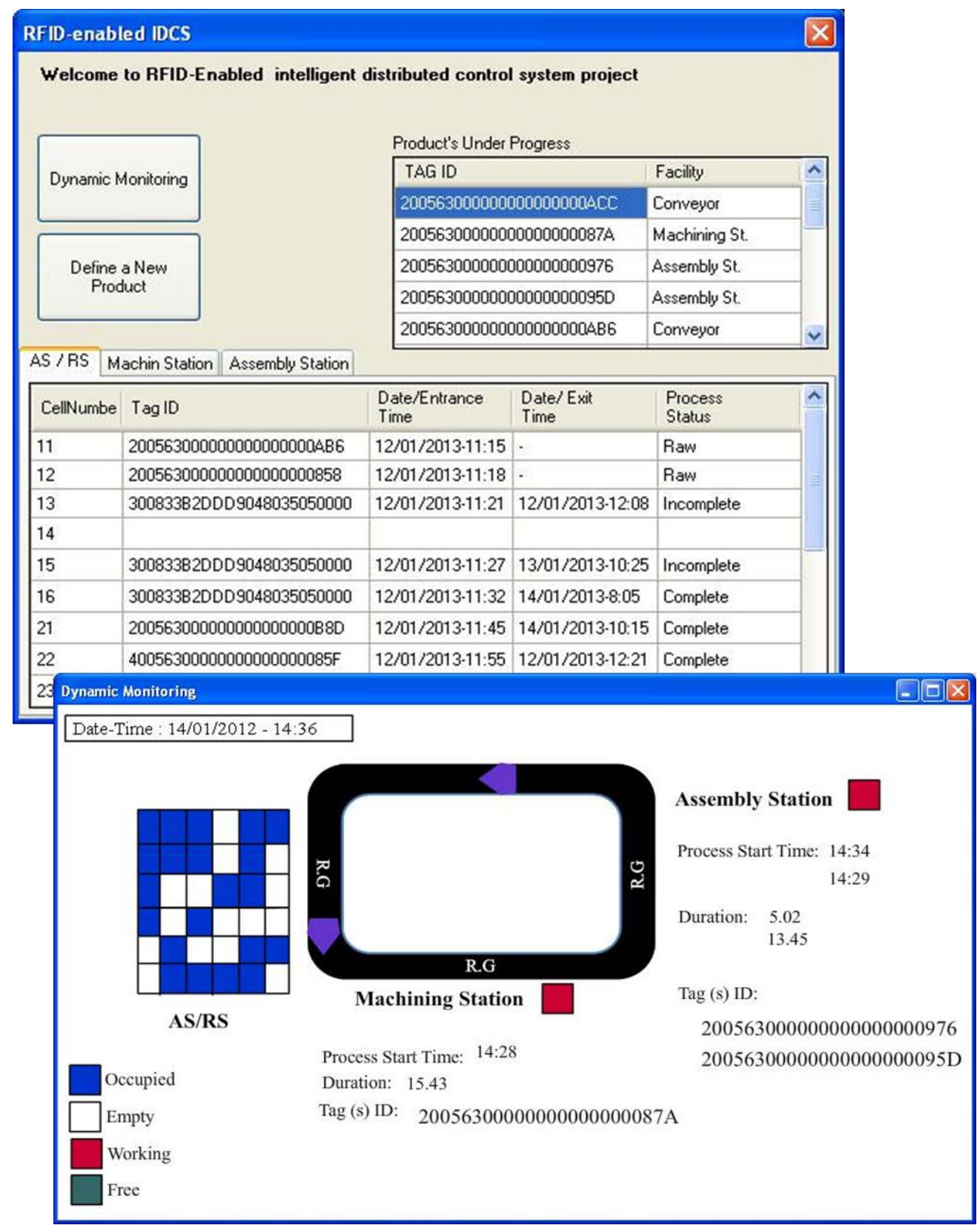

Figure 15: Shop monitoring system 


\section{CONCLUSION}

In this paper, we proposed an architecture for structural modelling of RFID-enabled IDCSs. This architecture, which comprises three distinct phases (system requirements gathering, design and development, and implementation), is meant to increase the flexibility and reconfigurability of current manufacturing systems, and to make the re-design of these systems more accessible and re-usable, through a common model structure. The models in this structure can be adapted to a variety of FMS systems and can easily incorporate changes and extensions made at a later stage. The use of the object-oriented approach for structural modelling was an effective support in the design of the system. UML provided a consistent notation for the creation and representation of the classes and detailed attributes for the design of the RFID-enabled IDCS, and for the development of the experimental software system.

In applying the proposed architecture to other manufacturing facilities, the following actions are essential:

- Highlighting the manufacturing resources that exist on the cell's stations, as well as the processes supported at those stations.

- Developing an appropriate use case diagram for the cell. The actor of the cell is the 'operator' and the main use case of the cell is HMl, which is in charge of the control and monitoring of the cell. Each of the stations manifests a sub-use case for the cell.

- $\quad$ Expanding the cell's class structure using the proposed generic class diagram.

- Developing the station's object diagram, including its RFID-gate.

- Developing the station's sequence diagrams based on its resources and processes, with emphasis on RFID-gate interactions.

- Developing the cell activity and deployment diagram based on previous steps.

The RFID-enabled IDCS described in this study is currently used at the FMS laboratory of the Eastern Mediterranean University. Additional experiments have been conducted to verify the effectiveness of the developed control system. From the authors' observations, the initialisation of the IDCS is much faster than centralised systems because the local processors are initialised faster than the host computer. Centralised systems suffer from a lack of flexibility, whereas in distributed systems, flexibility is achieved by utilising RFID technology. In addition, real-time re-configuration is one of the most important characteristics of the proposed RFID-enabled IDCS, allowing system re-configuration to be performed online. On the other hand, in centralised control systems, re-configurations are performed offline; therefore, such systems are less robust against failures. Manufacturing facilities are highly prone to failure, especially at the sensor level. So the control system should be sufficiently robust in the event of any failure. The required robustness is achieved by the RFID-enabled IDCS, allowing affected devices to respond to failures without any other devices.

The RFID-enabled IDCS was validated at cell level, but it would benefit from being tested at higher manufacturing levels (e.g., enterprise or factory level). Furthermore, it would be useful to investigate how applicable the IDCS structure is to supporting other manufacturing systems. Throughout this broad research work, a knowledge model for the developed multiagent system framework was defined; the results obtained will be reported in a future paper. The authors intend to investigate how this IDCS could be used by wireless sensor networks (WSN), and to explore the differences between RFID technology and WSN to improve definitions and to contribute to state-of-the-art systems.

\section{REFERENCES}

[1] Chungoora, N. \& Young, R.I.M. 2011. The configuration of design and manufacture knowledge models from a heavyweight ontological foundation. International Journal of Production Research, 49 (15), pp. 4701-4725. 
[2] Barenji, R.V., Hashemipour, M. \& Guerra-Zubiaga, D.A. (2014). A framework for modeling enterprise competencies: from theory to practice in enterprise architecture. International J ournal of Computer Integrated Manufacturing, (ahead-of-print), 1-20.

[3] Barenji, R.V., Hashemipour, M. \& Guerra-Zubiaga, D.A. 2013. Toward a modeling framework for organizational competency. In Technological Innovation for the Internet of Things. Berlin and Heidelberg: Springer, pp. 142-151.

[4] Kamioka, K., Kamioka, E. \& Yamada, S. 2007. An FR-ID driven holonic control scheme for production control systems. In Intelligent Pervasive Computing, 2007. IPC. The 2007 International Conference on IEEE, pp. 508-514.

[5] Martínez-Sala, A.S., Egea-López, E., García-Sánchez, F. \& García-Haro, J. 2009. Tracking of returnable packaging and transport units with active RFID in the grocery supply chain. Computers in Industry, 60 (3), pp. 161-171.

[6] Makris, S., Michalos, G. \& Chryssolouris, G. 2012. RFID driven robotic assembly for random mix manufacturing. Robotics and Computer-Integrated Manufacturing, 28 (3), pp. 359-365.

[7] Chen, K.Y. 2012. Cell controller design for RFID based flexible manufacturing systems. International J ournal of Computer Integrated Manufacturing, 25 (1), pp. 35-50.

[8] Barenji, A.V., Barenji, R.V. \& Sefidgari, B.L. 2013. An RFID-enabled distributed control and monitoring system for a manufacturing system. Third IEEE International Conference on Innovative Computing Technology (INTECH), 2013, London, pp. 498-503.

[9] Wu, C.S., Randhawa, S. \& Burhanuddin, S. 1998. An integration architecture for flexible manufacturing cells. The International Journal of Advanced Manufacturing Technology, 14(4), pp. 286-297.

[10] Chow, H.K., Choy, K.L., Lee, W.B., \& Lau, K.C. 2006. Design of a RFID case-based resource management system for warehouse operations. Expert Systems with Applications, 30 (4), pp. 561-576.

[11] Ilie-Zudor, E., Kemény, Z., van Blommestein, F., Monostori, L. \& van der Meulen, A. 2011. A survey of applications and requirements of unique identification systems and RFID techniques. Computers in Industry, 62 (3), pp. 227-252.

[12] Günther, O.P., Kletti, W. \& Kubach, U. 2008. RFID in Manufacturing. Springer.

[13] Wang, J., Luo, Z. \& Wong, E.C. 2010. RFID-enabled tracking in flexible assembly line. The International J ournal of Advanced Manufacturing Technology, 46 (1-4), pp. 351-360.

[14] McFarlane, D., Sarma, S., Chirn, J.L., Wong, C.Y. \& Ashton, K. 2003. Auto ID systems and intelligent manufacturing control. Engineering Applications of Artificial Intelligence, 16 (4), pp. 365-376.

[15] Huang, G.Q., Zhang, Y.F. \& J iang, P.Y. 2008. RFID-based wireless manufacturing for real-time management of job shop WIP inventories. The International J ournal of Advanced Manufacturing Technology, 36 (7-8), pp. 752-764

[16] Zhang, Y., Jiang, P. \& Huang, G. 2008. RFID-based smart kanbans for just-in-time manufacturing. International J ournal of Materials and Product Technology, 33 (1), pp. 170-184.

[17] Satoh, I. 2006. Location-based services in ubiquitous computing environments. International J ournal on Digital Libraries, 6 (3), pp. 280-291.

[18] Bellifemine, F.L., Caire, G. \& Greenwood, D. 2007. Developing multi-agent systems with J ADE (Vol. 7), Wiley.

[19] Shafiq, M.O., Ding, Y. \& Fensel, D. 2006. Bridging multi agent systems and web services: Towards interoperability between software agents and semantic web services. In Enterprise Distributed Object Computing Conference, 2006. EDOC'06. 10th IEEE International, IEEE, pp. 8596.

[20] Tapia, D.I., Rodríguez, S., Bajo, J. \& Corchado, J.M. 2009. FUSION@, a SOA-based multi-agent architecture. In International Symposium on Distributed Computing and Artificial Intelligence 2008 (DCAI 2008). Berlin and Heidelberg: Springer, pp. 99-107.

[21] Erenay, O., Hashemipour, M. \& Kayaligil, S. 2002. Virtual reality in requirement analysis for CIM system development suitable for SMEs. International J ournal of Production Research, 40 (15), pp. 3693-3708.

[22] Vergidis, K., Tiwari, A. \& Majeed, B. 2008. Business process analysis and optimization: Beyond reengineering. IEEE Transactions on, Systems, Man, and Cybernetics, Part C: Applications and Reviews, 38 (1), pp. 69-82.

[23] Doomun, R. \& J ungum, N.V. 2008. Business process modelling, simulation and reengineering: Call centres. Business Process Management J ournal, 14 (6), pp. 838-848.

[24] Thimm, G., Lee, S.G. \& Ma, Y.S. 2006. Towards unified modeling of product lifecycles. Computers in Industry, 57 (4), pp. 331-341.

[25] Yu, J. \& Buyya, R. 2005. A taxonomy of workflow management systems for grid computing. J ournal of Grid Computing, 3 (3-4), pp. 171-200.

[26] Wang, B., Cao, Z., Yan, Y., Liu, W. \& Wang, Z. 2011. Fundamental technology for RFID-based supervisory control of shop floor production system. The International J ournal of Advanced Manufacturing Technology, 57 (9-12), pp. 1123-1141. 
[27] Liu, M.R., Zhang, Q.L., Ni, L.M. \& Tseng, M.M. 2005. An RFID-based distributed control system for mass customization manufacturing. In Parallel and Distributed Processing and Applications. Berlin and Heidelberg: Springer, pp. 1039-1049.

[28] Barenji, A.V., Barenji, R.V. \& Hashemipour, M. 2013. Structural modeling of a RFID-enabled reconfigurable architecture for a flexible manufacturing system. Proceedings of European Conference on Smart Objects, Systems and Technologies (SmartSysTech) (pp. 1-10). VDE.

[29] García, A., Chang, Y., Abarca, A. \& Oh, C. 2007. RFID enhanced MAS for warehouse management. International J ournal of Logistics, 10 (2), pp. 97-107.

[30] Sikora, R. \& Shaw, M.J. 1998. A multi-agent framework for the coordination and integration of information systems. Management Science, 44 (11-Part-2), pp. S65-S78.

[31] Krothapalli, N.K.C. \& Deshmukh, A.V. 1999. Design of negotiation protocols for multi-agent manufacturing systems. International J ournal of Production Research, 37 (7), pp. 1601-1624.

[32] Barenji, R.V., Barenji, A.V. \& Hashemipour, M. 2014. A multi-agent RFID-enabled distributed control system for a flexible manufacturing shop. The International Journal of Advanced Manufacturing Technology, pp. 1-19.

[33] Barenji, R.V. 2013. Towards a capability-based decision support system for a manufacturing shop. In Collaborative Systems for Reindustrialization. Berlin and Heidelberg: Springer, pp. 220227. 